Gut, 1978, 19, 240-243

\title{
Digestion of native collagen in the gut
}

\author{
MARGARET L. R. HARKNESS, R. D. HARKNESS, AND MARY F. VENN 1 \\ From the Department of Physiology, University College London, Gower Street, London
}

SUMMARY The digestion and absorption of collagen, native and artificially cross-linked, has been examined in the rat and the Gaboon viper, by feeding known quantities and measuring the hydroxyproline content of the faeces and of the contents of the gut at different levels, and comparing with an unabsorbable marker (polyethylene glycol). Incubation of collagen in vitro with pepsin at $37^{\circ} \mathrm{C}$ at pH 1.5 followed by trypsin or chymotrypsin converted about $40 \%$ into dialysable material.

Collagen is a major component of the diet of carnivores, forming about a fifth of the total body protein of a mammal (Harkness et al., 1958; Picou et al., 1966). A number of vertebrates swallow their prey whole-snakes, for example (Pope, 1961) while others eat everything including bone-for example, hyenas (Kruuk, 1972). A necessary preliminary to the digestion of hard tissues or a whole animal must be the solubilisation of the collagen that holds the tissues together. However, there seems to be no direct evidence that collagen is digested and absorbed, nor is it clear how it might be digested as the collagen molecule in vitro is normally resistant to attack by the proteases of the gastrointestinal tract because of its triple helical structure. We have examined the digestion and absorption of collagen by feeding known amounts to rats and snakes, and determining the hydroxyproline content of the faeces, and of the contents of the gut at different points. The results show that absorption takes place before the food reaches the large gut, so it would seem that bacteria are not involved. Evidence was obtained in vitro that pepsin in acid conditions can break down collagen sufficiently for it to be digested by pancreatic enzymes.

\section{Methods}

ANIMALS

Adult male rats, 3 months old, weighing $100-200 \mathrm{~g}$, from the local colony originally Wistar were used for most of the experiments but one was done on a Gaboon viper (Bitis gabonicus) that was about 61 cm (2 ft) long.

'Present address: Bone and Joint Research Unit, ARC Building, London Hospital Medical College, Turner Street, London E1.

Received for publication 17 October 1977

\section{EXPERIMENTAL PROCEDURES}

\section{Metabolic experiments}

The rats were trained to eat a quantity of food in a short period of time by feeding them once daily at the same time and removing the food after an hour. This training took about five days. Water was available continuously. Two sorts of experiment were done.

1. Rats were kept at $20^{\circ} \mathrm{C}$ in individual metabolism cages on grids through which faeces and urine fell and were separated below. Faeces were analysed for total hydroxyproline content before and after the addition of a known amount of collagen of various types to the diet.

The Gaboon viper (kept at $25^{\circ} \mathrm{C}$ in a gardener's plastic propagating box) was given mice to eat after a period of fasting and passage of a large stool representing the remains of the previous meal. The faeces representing the remains of the mice, identified by hair colour, were analysed when they were passed later.

2. Rats were given a meal to which a known amount of collagen had been added, together with an unabsorbable marker, polyethylene glycol, and killed later at intervals by a blow on the head and breaking the neck. The abdomen was opened quickly and Spencer Wells forceps put on the junctions at the lower end of stomach and small intestine, and also between the caecum and colon. The contents of the parts so separated were washed out and analysed for total hydroxyproline, and the marker.

\section{Food}

Cubes of MRC Diet were crushed and mixed with water to make a solid mass $\left(20 \mathrm{~g}+16 \mathrm{ml} \mathrm{H}_{2} \mathrm{O}\right)$. A weighed quantity of this was put in an earthenware pot with a narrow opening at the top so that the rats ate but did not spill the food. Food not eaten, 
generally only a small proportion of that given, was weighed. The collagenous material added to the food was chopped up into pieces about $2 \mathrm{~mm}$ square or long in the case of rat tail tendon. The following types of collagen were used:

1. Fresh rat tail tendon ( 3 months old).

2. Rat tail tendon treated with sodium borohydride $\left(0.2 \mathrm{M}, 4^{\circ} \mathrm{C} 1 \mathrm{~h}\right)$ to stabilise crosslinks.

3. Rat tail tendon treated with glutaraldehyde $\left(1 \%\right.$ w.v. $\left.4^{\circ} \mathrm{C} 1 \mathrm{~h}\right)$ to introduce additional cross links.

4. Tendon of foreleg flexor muscles of sheep.

5. Cartilage of bovine trachea.

When polyethylene glycol was used, $18 \mathrm{mg}$ was added per $\mathbf{g}$ of wet food diet.

Preparation of faeces, diet, and gut contents for analysis

The faeces and samples of the diet were extracted with trichloracetic acid (TCA) to separate collagenous material (Fitch et al., 1955). Faeces and diet were extracted four times for 30 minutes with 10 times their weight of $5 \% \mathrm{TCA}$, twice at $90^{\circ} \mathrm{C}$ and twice at room temperature. After each extraction the mixture was centrifuged and the supernatant decanted. The four supernatants were bulked and taken to dryness on a water bath. They were then taken up in $6 \mathrm{~N} \mathrm{HCl}$, hydrolysed at $25 \mathrm{lb} / \mathrm{sq}$ in $\left(1.75 \mathrm{~kg} / \mathrm{cm}^{2}\right)$ in sealed tubes $\left(115^{\circ} \mathrm{C}\right.$ approx.) and analysed for hydroxyproline.

The gut contents were analysed by the same procedure as the faeces except that the contents were first mixed with water and made to a known volume. A sample $(1 \mathrm{ml})$ was taken for estimation of polyethylene glycol. The remainder was treated with TCA as above.

Bodies of control mice (litter mates of those fed to the Gaboon viper) were analysed for total collagen by boiling them in 5\% TCA for two hours, homogenising in a Waring blender, making to a known volume and filtering. An aliquot was taken to dryness and analysed for hydroxyproline by the usual procedure.

A further extract of the solid with hot $5 \%$ TCA was analysed for hydroxyproline to make sure the extraction procedure was adequate. The amount found in this second extract was negligible.

The TCA extraction method was checked by adding known amounts of collagen, in the form of chopped rat tail tendon, to faeces and to samples of diet before extracting and analysing. Thirty-seven milligrams of collagen added gave an average recovery of $35.9 \mathrm{mg}$ an analysis.

Solubilisation and digestion of collagen in vitro Fresh rat or bovine tendon was chopped coarsely with scissors. One gram (wet weight) of tendon was incubated on a Roller mix with $20 \mathrm{ml}$ pepsin, $\mathrm{HCl}$ or gastric juice at $\mathrm{pH} 1.5$ for two hours at $37^{\circ} \mathrm{C}$. After treatment the solution was centrifuged for one hour at $25000 \mathrm{rpm}$ at $4^{\circ} \mathrm{C}$. The supernatant was removed and made to known volume and an aliquot taken for collagen analysis. Human gastric juice was obtained from University College Hospital and used without dilution. Rat tail tendon collagen soluble in pepsin or $\mathrm{HCl}$ was subsequently made to $0.01 \mathrm{M} \mathrm{Na} \mathrm{HCO}_{4}, 0.145 \mathrm{NaCl}$, and titrated to pH 7.0. It was then digested with neutral proteases. Trypsin or chymotrypsin was added to give a final concentration of $0.5 \mathrm{mg} / \mathrm{ml}$ and the solutions incubated for 18 hours at $37^{\circ} \mathrm{C}$. The solutions were then dialysed against phosphate buffer for 24 hours and the solutions inside and outside the dialysis sack were taken to dryness and analysed for collagen content.

\section{Chemical methods}

Hydroxyproline (in the acid hydrolysate) was measured by the method of Stegemann (1958) modified for automated analysis by Grant (1964). Gel electrophoresis was done by the method of Stark and Kühn (1968). Polyethylene glycol was measured by the method of Malawer and Powell (1967).

\section{Results}

ESTIMATION OF COLLAGEN DIGESTION BY EXAMINATION OF FAECAL HYDROXYPROLINE Results are shown (for rats) in Table 1. All the collagen of rat tail tendon and nearly all that of sheep tendon was absorbed, while only $60 \%$ of cartilage collagen and $39 \%$ of highly cross-linked collagen was absorbed.

The Gaboon viper ate six mice, first one, then five a week later. Faeces were produced three weeks after the second meal. Two mice taken from the same litter as the ones that were eaten weighed 21 and $20 \mathrm{~g}$ and contained 71 and $74 \mathrm{mg}$ hydroxyproline, an average of $72.5 \mathrm{mg}$ to give an estimated total of $435 \mathrm{mg}$ hydroxyproline ingested from the six mice. The faeces contained $3 \cdot 1 \mathrm{mg}$ hydroxyproline and a large quantity of hair. As these animals generally void the unabsorbed residue of a meal in a single mass, one can conclude that $99 \%$ or virtually all the collagen in the mice was digested and absorbed.

EXAMINATION OF CONTENTS OF DIFFERENT PARTS OF GUT AFTER A MEAL CONTAINING COLLAGEN

The results of analysis of the contents of the different parts of the gut after meals containing collagen are 
Table 1 Effect of adding collagen to food on output of hydroxyproline in faeces, in rats weighing approximately $100 \mathrm{~g}$

\begin{tabular}{|c|c|c|c|c|}
\hline \multirow[t]{2}{*}{ Source of collagen } & \multirow{2}{*}{$\begin{array}{l}\text { Amount of } \\
\text { collagen } \\
\text { added to } \\
\text { food } \\
\text { (mg/hypro) }\end{array}$} & \multicolumn{2}{|c|}{$\begin{array}{l}\text { Faecal hypro } \\
\text { (mg/day) }\end{array}$} & \multirow[t]{2}{*}{$\begin{array}{l}\% \text { Collagen } \\
\text { absorbed }\end{array}$} \\
\hline & & Before & After & \\
\hline \multirow{2}{*}{ Tendon (rat tail) } & $\int 33.5$ & 1.54 & $1 \cdot 11$ & 104 \\
\hline & $33 \cdot 5$ & $1 \cdot 37$ & $1 \cdot 47$ & 99 \\
\hline \multirow[t]{2}{*}{ Tendon (sheep) } & $\int 9 \cdot 0$ & $1 \cdot 78$ & $1 \cdot 46$ & 90 \\
\hline & $9 \cdot 0$ & 0.95 & 1.41 & 85 \\
\hline \multirow{2}{*}{$\begin{array}{l}\text { Cartilage (bovine } \\
\text { trachea) }\end{array}$} & $4 \cdot 1$ & 0.71 & $1 \cdot 23$ & 61 \\
\hline & $4 \cdot 4$ & 0.57 & 1.07 & 65 \\
\hline \multirow{2}{*}{ Tendon (borohydride) } & $\int 5.8$ & 0.91 & 2.50 & 37 \\
\hline & $10 \cdot 7$ & $1 \cdot 39$ & $2 \cdot 02$ & 86 \\
\hline $\begin{array}{l}\text { Tendon (glutar- } \\
\text { aldehyde) }\end{array}$ & 6.9 & 0.63 & $2 \cdot 45$ & 39 \\
\hline
\end{tabular}

The faecal hydroxyproline 'before' is the amount in the 24 hours before addition of collagen to the diet. The figure for 'after' is the mean of the three days after feeding collagen. The figure for ' $\%$ absorbed' is calculated from amount added to food and the difference between the output in the three days after feeding and the output expected from the figure for the day before. Tendon (borohydride) and tendon (glutaraldehyde) refer to rat tail tendon previously treated with sodium borohydride or glutaraldehyde.

given in the Figure. Little hydroxyproline was found in any part of the digestive tract except the stomach, though the analyses for polyethylene glycol showed that the residues of the meal had passed through into the large gut. It would seem that the collagen is digested and absorbed before the end of the small gut.
DIGESTION OF COLLAGEN in vitro More than $90 \%$ rat tail tendon was soluble in pepsin, gastric juice, and $\mathrm{HCl}$ in two hours at $37^{\circ} \mathrm{C}$. Bovine tendon was insoluble in $\mathrm{HCl}$ but was digested by pepsin, though to a lesser extent than rat tail tendon (Table 2). This may reflect an age difference in the tissues concerned. Acrylamide gel electrophoresis of enzyme solubilised collagen showed a number of bands that did not correspond with the single or double chains as seen when collagen was solubilised in acid alone but going further into the gel. Very little material, however, was dialysable. When pepsin or acid soluble collagen was subsequently incubated in trypsin or chymotrypsin approximately $40 \%$ was dialysable, although less than $1 \%$ was dialysable after incubation in buffer.

Table 2 Effect of gastric enzymes on solubilisation of rat tail tendon (4-week rat) and bovine tendon collagen*

\begin{tabular}{lll}
\hline Tissue & Enzyme & $\begin{array}{c}\% \text { Collagen } \\
\text { solubilised }\end{array}$ \\
\hline Rat tail tendon & Gastric juice & $97 \cdot 7$ \\
& HCl $(0.015 \mathrm{~N})$ & 95.4 \\
& Pepsin & 96.5 \\
& $(0.25 \mathrm{mg} / \mathrm{ml})$ & 0.0 \\
& Phosphate buffer & 0.5 \\
BH 7.4 & 0.5 \\
& HCl $(0.015 \mathrm{~N})$ & 37.00 \\
\hline
\end{tabular}

$* 20 \mathrm{ml}$ solution $\mathrm{pH} 1.5$ two hours at $37^{\circ} \mathrm{C}$.

Figure Distribution of polyethylene glycol and collagen in the gut after feeding them by mouth. 


\section{Discussion}

It is clear frorn the results that native collagen is digested and absorbed by the rat and a Gaboon viper. In the rat the evidence was that it was absorbed in the small gut, so that presumably bacteria are not concerned in the breakdown. From the experiments in vitro it seems that the combination of pepsin at acid $\mathrm{pH}$ in the stomach followed by neutral proteases in pancreatic juice could break down the triple helix.

An interesting problem in relation to digestion of collagen arises in intestinal parasites with a collagenous cuticle like nematodes. Their survival would be understandable if passage through the stomach is a necessary preliminary to digestion of collagenous materials by pancreatic proteases.

\section{References}

Fitch, S. M., Harkness, M. L. R., and Harkness, R. D.
(1955). Extraction of collagen from tissues. Nature (Lond.), 176, 163.

Grant, R. A. (1964). Estimation of hydroxyproline by the autoanalyser. Journal of Clinical Pathology, 17, 685-686.

Harkness, M. L. R., Harkness, R. D., and James, D. W. (1958). The effect of a protein-free diet on the collagen content of mice. Journal of Physiology, 144, 307-313.

Kruuk, H. (1972). The Spotted Hyena. University of Chicago Press: Chicago.

Malawer, S. J., and Powell, D. W. (1967). An improved turbidimetric analysis of polyethylene glycol utilizing an emulsifier. Gastroenterology, 53, 250-256.

Picou, D., Halliday, D., and Garrow, J. S. (1966). Total body protein, collagen and non-collagen protein in infantile protein malnutrition. Clinical Science, 30, 345-351.

Pope, C. H. (1961). The Giant Snakes. Routledge, Kegan Paul: London.

Stark, M., and Kühn, K. (1968). The properties of molecular fragments obtained on treating calf-skin collagen with collagenase from Clostridium histolyticum. European Journal of Biochemistry, 6, 534-541.

Stegemann, H. (1958). Mikrobestimmung von Hydroxyprolin mit Chloramin-T und p-Dimethylaminobenzaldehyd. Hoppe-Seylers Zeitschrift für physiologische Chem., 311, 41-45. 